\title{
Ouditief Waarneembare Foute by Verbale Apraksie: Aanduidings van die Aard van die Afwyking
}

\author{
A van der Merwe, D Phil (Pretoria) \\ Departement Spraakheelkunde en Oudiologie, \\ Universiteit van Pretoria \\ I C Uys, D Phil (Pretoria) \\ Departement Spraakheelkunde en Oudiologie, \\ Universiteit van Pretoria \\ J M Loots, D Sc (Fisiologie) (Pretoria) \\ Instituut vir Sportnavorsing, \\ Universiteit van Pretoria \\ R J Grimbeek, B Sc (Hons) (Pretoria) \\ Departement Statistiek, \\ Universiteit van Pretoria
}

\section{OPSOMMING}

Baie vrae bestaan nog oor die aard en oorsake van die-simptome van verbale apraksie. Tydens 'n ondersoek na die invloed van kontekstuele faktore op die ouditief waarneembare foute by verbale apraksie (Vä der Menwe, Uys, Loots en Grimbeek, 1987) is simptome wat aanduidings verskaf-van die aard van die afwyking waargeneem. Hierdie simptome word verder geanaliseer in hierdie artikel. Die frekwensie en tipe foute by herhalde produksie van onsineenhede wat sistematies gevarieer is in klankstruktuur en artikulasie-eien. skappe is nagegaan by vier persone met verworwe verbale apraksie en een persoon met verbale ontwikkelingsapraksie. Daar is onder andere waargeneem dat suiwer verbale apraksie gekenmerk word deur distorsie van klanke wat soms soos vervangings klink, afbakening van lettergrepe en veranderinge in die struktuur van 'n eenheid met veral 'n neiging om dit te vereenvoudig na ' $n K V$-senheid of duplisering daarvan. Daar is moontlik ' $n$ onderliggende onvermoë om die kritiese ekwivalensiegrense en bewegings te handhaaf, klanke vinnig en onveranderlik vooruit te voer en om spraak vooruit te beplan.

A'B́STRACT

Many questions on the nature and causes of the symptoms of verbal apraxia still exist. In the investigation of the influence of contextual factors on auditorily perceived symptoms of verbal apraxia (Van der Merwe, Uys, Loots and Grimbeek, 1987) symptoms indicative of the nature of the disorder were recorded and these are further analysed in this article. The frequency and nature of mistakes made during repeated productions of nonsense units which are systematically varied in sound structure and articulatory features were determined in the speech of four patients with acquired verbal apraxia and one patient with developmental verbal apraxia. The most prominent indications were that pure verbal apraxia is characterised by sound distortions which ore sometimes perceived as substitutions, intersyllabic pauses and changes in the sound structure of units manifesting a tendency to simplify and change the structure to a $C V$-unit or reduplication thereof. There possibly is an underlying inability to keep movements within the critical boundaries of motor equivalence to quickly and invariantly feed sounds forward and to preplan speech.

Navorsing oor verbale apraksie is in die verlede hoofsaaklik gerig op simptoombeskrywings en die kenmerkende simptome van suiwer verbale apraksie is mettertyd geïdentifiseer. Daar was aanvanklik geen eenstemmigheid oor die simptome van die afwyking nie en die suiwer vorm is selfs nog gedurende die vroeë tagtigerjare deur sommige navorsers nie onderskei van Broca afasie en fonemiese parafasie nie (Martin, 1974; Keller, 1978; Miceli, Gainotti, Caltagirone \& Masullo, 1980; Guyard, Sabouraud \& Gagnepain, 1981). Die implikasie van hierdie verwarring was dat simptome van afasie aan verbale apraksie toegeskryf is en sodoende is kennis en navorsing oor hierdie omstrede en komplekse afwyking benadeel.
Die oortuiging dat daar wel 'n suiwer vorm van verbale apraksie is, het mettertyd meer algemeen posgevat en in 1983 stel Kent en Rosenbek en ook Collins, Rosenbek en Wertz kriteria vir die seleksie van hul verbaal apraktiese proefpersone ten einde te verseker dat 'n suiwer vorm van verbale apraksie ondersoek word. Hierdie kriteria kom opsom. mend daarop neer dat die sprekers onvlot spraak, próbeeren-tref-artikulasiebewegings, pogings tot selfkorreksie, onkonstantheid in die foute by herhaalde produksie van dieselfde woord en disprosodie vertoon, maar fraselengte en grammatikale vorm is normaal of byna normal. Deur te verseker dat die afwyking in sy suiwer vorm ondersoek word; word die weg gebaan om die aard van verbale aprak- 
sie werklik bloot te lê deur navorsing.

Talle vrae oor die aard van verbale apraksie bestaan tans nog. Verbale apraksie word algemeen in definisies as ' $n$ afwyking in spraakprogrammering beskryf, maar in werklikheid is daar baie min bekend oor wat spraakprogrammering werklik behels.

Darley, Aronson \& Brown $(1975$ : 255) definieer verbale apraksie as:

"... an articulatory disorder resulting from impairment, due to brain damage, of the capacity to program the positioning of speech muscalature for the volitional production of phonemes and the sequencing of muscle movements for the production of words'.

Programmering word in hierdie definisie dus beperk tot posisionering van strukture en die volgordebepaling van bewegings. Dit is ook nie duidelik in die definisie of die programmeringsprobleem ' $\mathrm{n}$ afwyking in die beplanning van die aksie is of ' $n$ afwyking wat intree tydens die uitvoer van die beweging nie.

La Pointe (1982: 7) definieer verbale apraksie as:

"... A neurogenic phonologic disorder resulting from sensori-motor impairment of the capacity to select, program and/or execute in coordinated and normally-timed sequences, the positioning of the speech musculature for the volitional production of speech sounds".

In hierdie definisie word onderskei tussen seleksie, programmering en uitvoering. Die implikasie hiervan is dat programmering nie seleksie insluit nie. Dit is ook nie volkome duidelik wat gekoördineer moet word nie. Buckingham het reeds in 1979 die vaagheid van terme soos programmering, wankoördinering en volgorde gekritiseer.

Die onsekerheid oor wat spraakprogrammering of beplanning behels en wat die aard van 'n afwyking daarin is, hang nou saam met die vraag oor die stadium van spraakproduk. sie wat defek is by verbale apraksie. Tydens spraakproduksie is daar waarskynlik sprake van fonologiese en in ' $n$ volgende stadium van motoriese beplanning van ' $n$ uiting. Die fonologiese eienskappe van ' $n$ uiting is ' $n$ linguistiese kom. ponent van spraakproduksie. Navorsers met 'n linguistiese oriëntasie is van mening dat spraak en taal interafhanklik en onafskeidbaar is (Jakobson, Fant \& Halle, 1967; Martin, 1974) en die fonologiese komponent verteenwoordig die tussenvlak tussen spraakproduksie (fonetiese aspekte) en taal [Edwards \& Shriberg, 1983]. Differensiële aantasting van òf taal of spraak is dus volgens die linguis nie moontlik nie (Martin, 1974). Vanuit so ' $n$ uitgangspunt is verbale apraksie as ' $\mathrm{n}$ fonologiese probleem beskou en in die literatuur het die dispuut oor die aard van die afwyking dan ook hoofsaaklik gesentreer om die vraagstuk van verbale apraksie as 'n 'motoriese teenoor 'n fonologiese probleem (Martin, 1974; Aten, Darley, Deal \& Johns, 1975; Kent \& Rosenbek, 1983). Wesenlik handel dit dus oor die skeiding van linguistiese (fonologiese) en motoriese gedrag.

In hul bespreking oor die kwessie van verbale apraksie as ' $\mathrm{n}$ motoriese teenoor ' $n$ fonologiese probleem, sê Kent en Rosenbek (1983: 245) dat minstens sommige van die foute:
"... do not seem to fall in the domain of phonology because as the term is commonly understood, phonology is not intended to explain the details of timing and coordination in speech".

Hulle sê verder ook dat hulle nie daarop aanspraak maak dat verbale apraksie slegs 'n motoriese probleem is nie en dat dit montlik is dat beide tipes probleme saam voorkom.

In die bogenoemde definisie van La Pointe (1982) omseil hy die twispunt deur dit ' $n$ fonologiese afwyking te noem, maar dan ' $n$ beskrywing te gee van die motoriese probleme. Itoh en sy medewerkers (Itoh, Sasanuma \& Ushijima, 1979; Itoh \& Sasanuma, 1984) wat intensiewe ondersoeke oor die temporale versteuring van spraakbewegings by verbale apraksie gedoen het, stel dit onomwonde dat verbale apraksie na hul mening ' $n$ afwyking in programmering van spraakmotoriek is. Volgens hierdie navorsers is distorsie van klanke die kernsimptoom van verbale apraksie en is dit die gevolg van temporale versteurings van spraakbewegings.

Vroeër is algemeen aanvaar dat klankvervangings die kenmerkendste simptoom van verbale apraksie is (Shankweiler \& Harris, 1966; La Pointe \& Johns, 1975; Keller, 1978; Wertz, La Pointe \& Rosenbek, 1984: 52 |. Dit is waarskynlik omdat die gevalle wat ondersoek is, ook gepaardgaande Broca afasie en/of fonemiese parafasie en dus ware klankvervangings vertoon het en omdat breë fonetiese transkripsies gebruik is om die spraakfoute te beskryf |Itoh \& Sasanuma, 1984). Op grond van hierdie transkripsiemetode word distorsies dus as vervangings beskryf. Deur gebruik te maak van eng fonetiese transkripsies, soos in hierdie studie beskryf word, kan distorsiefoute beter nagegaan word.

Tydens die ondersoek na die invloed van sekere kontekstuele faktore op die ouditief waarneembare foute by verbale apraksie (Van der Merwe, Uys, Loots \& Grimbeek, 1987) is simptome waargeneem wat aanduidings verskaf van die aard van die afwyking maar wat nie in daardie artikel volledig aangegee is nie. Die doel van die huidige artikel is om hierdie addisionele waarnemings te beskryf en te wys op die implikasies wat dit inhou vir ' $n$ beter begrip van die aard van verbale apraksie. Heelwat ander perseptuele studies oor die simptome van verbale apraksie is in! die verlede uitgevoer (La Pointe \& Johns, 1975; Johns \& Darley, 1970, Dunlop \& Marquardt, 1977). Hierdie studie is egter uniek in die sin dat die materiaal volkome gekontroleerd is in klankstruktuur en artikulasie-eienskappe, ' $n$ eng transkripsiemetode gebruik is wat ook voorsiening maak vir'die voorkoms van klankdistorsie en vier agtereenvolgende herhalings van die onsineenhede ontleed is. Hierdie faktore bring mee dat die waarnemings binne hoogs gekontroleerde toestande kan plaasvind en ruimte gelaat word vir volledige beskrywings van gedrag.

\section{METODE}

Doel

Om te bepaal wat die frekwensie en tipe verbaal apraktiese foute is wat voorkom by herhaalde produksies van onsin. hede wat sistematies gevarieer is in klankstruktuur en artikulasie-eienskappe ten einde aanduidings te verkry van die aard van die afwyking by verbale apraksie. 


\section{Eksperimentele ontwerp}

Die proefpersone, luisteraars, materiaal en prosedure van hierdie ondersoek is reeds volledig beskryf in die voorafgaande artikel (Van der Merwe et al. 1987) en word dus nie hier herhaal nie. Kortliks kan wel gemeld word dat vier persone met verworwe verbale apraksie en een persoon met verbale ontwikkelingsapraksie as proefpersone gebruik is. Die kriterium is gestel dat 'n suiwer verbale apraksie vertoon moet word

Wat die materiaal betref, is onsineenhede wat gekontroleer is in klankstruktuur en artikulasie-eienskappe ontwikkel (Van der Merwe, 1986). Die volgende vyf klankstruktuurgroepe (S), het elk agt eenhede bevat en elke eenheid is vier keer herhaal:

Struktuurgroep 1: K1 V1 K1 V2

Struktuurgroep 2: K1 V1 K2 V2

Struktuurgroep 3: K1 V1 K2 V2 K3

Struktuurgroep 4: K1 V1 K2

Struktuurgroep 5: K1 V1 K2 V2 K3 V3 K4 en K1 V1 K2 V2 K3 V2 K4

Vir die analise van die data is 'n lys saamgestel van alle spraakfoute wat voorgekom het by die vyf proefpersone. Hierdie foute is geklassifiseer in die volgende sewe foutkategorieë:
A. Vervangings
B. Verandering van die struktuur van die eenheid
C. Klankdistorsie
D. Afwykings in temporale vloei
E. Afwykings in vlotheid
F. Spraakfoute gevolg deur selfkorreksie
G. Afwykings in prosodie

Die tipe foute in elke foutkategorie verskyn volledig in die bylae van die vorige artikel en in tabelle 1 tot 7 van hierdie artikel.

\section{'}

Die somtotaal van elke verskillende tipe fout oor vier herhalings van ' $n$ spesifieke eenheid is bepaal vir elke proefpersoon. Die totale aantal kere wat 'n spesifieke fout in elke klankstruktuurgroep voorkom, is daarna bereken en hierdie totale word in tabelle 1 tot 7 aangegee. ' $n$ Analise van die data het getoon dat artikulasie-eienskappe nie 'n statisties aantoonbare effek het ọ die tipe foute wat voorkom nie (Van der Merwe, 1986; Van der Merwe et al. 1987) en daar- om word slegs die tipe foute by die verskillende klankstruktuurgroepe bespreek.

\section{RESULTATE EN BESPREKING}

Afwykings in temporale vloei het die hoogste frekwensie van voorkoms, naamlik $35,6 \%$ vertoon en daarna distorsiefoute $(30,7 \%)$, verandering van struktuur $\{9,6 \%\}$, afwykings in prosodie $\{9,6 \%)$, vervangings $(8,5 \%)$, afwykings in vlotheid $(4,7 \%)$ en foute gevolg deur selfkorreksie $\{1,3 \%\}$. Elk van hierdie foutkategorieë word vervolgens bespreek.

\section{Vervangings}

Die opsommende gegewens in tabel 1 toon aan dat vervang ings met eenheidskonsonante (konsonante wat in die doelwiteenheid teenwoordig is/ die meeste voorkom. Dit is veral by S3 en S5 wat oor die algemeen die meeste foute tot gevolg gehad het, waargeneem. By klankstruktuur 5 is daar 75 vervangings met eenheidskonsonante maar daar is geen sodanige foute by $\mathrm{S} 1$ en $\mathrm{S} 4$ nie.

'n Vervanging met ' $n$ eenheidskonsonant impliseer dat die volgorde van klanke in die eenheid foutief is. Dit weerspieël dus klank volgordeningsprobleme en nie seleksieprobleme nie. Klankstrukture 3 en 5 is die langste eenhede en stel dus die hoogste eise met betrekking tot die volgordening van klanke asook geheue vir die klanke wat voorgekom het in die eenheid. Die spreker selekteer dus die korrekte foneem, maar kombineer dan die doelwitklanke in die verkeerde volgorde. Hierdie simptoom kan as ' $n$ fonologiese probleem geklassifiseer word omdat dit 'n afwyking in fonologiese beplanning weerspieël. Dit is egter belangrik om daarop te wys dat die probleem nie konstant teenwoordig was nie. TYdens herhaalde produksie van dieselfde uiting was die eenheid soms korrek en soms nie. Dit is onwaarskynlik dat fonologiese kennis so labiel kan wees en die simptoom weerspieël dus waarskynlik nie 'n afwyking in fonologiese kennis nie maar eerder ' $n$ probleem wat ontstaan tydens produksie.

'n Vraag wat ontstaan, is of die beeld van die uiting soos wat die ondersoeker dit geproduseer het nie vervaag in die geheue van die verbaal apraktiese spreker en dan lei tot foutiewe volgordening van konsonante en vervangings met eenheidskonsonante nie. Dit is egter nie die geval nie, want dit was 'n algemene verskynsel dat die eerste herhalings foutief was, maar die laaste een dan weer korrek. Die persoon behou dus ' $n$ beeld van wat geproduseer moet word, maar by herhaalde produksie is dit onkonstant korrek. Die feit dat die uiting soms korrek is dui sterk daarop dat die

Tabel 1: Vervangingsfoute by die verskillende klankstruktuurgroepe:

\begin{tabular}{|c|c|c|c|c|c|c|}
\hline \multirow{3}{*}{$\begin{array}{l}\text { Klankstruk- } \\
\text { tuurgroepe }\end{array}$} & \multicolumn{6}{|c|}{ Vervangingsfoute } \\
\hline & \multicolumn{2}{|c|}{ Konsonant } & \multicolumn{2}{|c|}{ Vokaal } & \multirow{2}{*}{$\begin{array}{l}\text { Letter- } \\
\text { greep }\end{array}$} & \multirow{2}{*}{ Totaal } \\
\hline & $\begin{array}{l}\text { Eenheids- } \\
\text { klank }\end{array}$ & $\begin{array}{c}\text { Nie-een- } \\
\text { heidsklank }\end{array}$ & $\begin{array}{l}\text { Eenheids- } \\
\text { klank }\end{array}$ & $\begin{array}{c}\text { Nie-een- } \\
\text { heidsklank }\end{array}$ & & \\
\hline 1 & 0 & 8 & 1 & 16 & 0 & $25\{11,7 \%\}$ \\
\hline 2 & 3 & 3 & 1 & 15 & 0 & $22\{10,3 \%\}$ \\
\hline 3 & 19 & 14 & 0 & 2 & 2 & $37(17,3 \%)$ \\
\hline 4 & 0 & 4 & 0 & 0 & 0 & $4(1,9 \%)$ \\
\hline 5 & 75 & 24 & 7 & 16 & 4 & $126(58,8 \%)$ \\
\hline Totaal & $1 \begin{array}{c}97 \\
(45,3 \%)\end{array}$ & $\begin{array}{c}53 \\
\{24,8 \%\}\end{array}$ & $\begin{array}{c}9 \\
(4,2 \%)\end{array}$ & $\begin{array}{c}49 \\
(22,9 \%)\end{array}$ & $\begin{array}{c}6 \\
(2,8 \%)\end{array}$ & 214 \\
\hline
\end{tabular}


spreker 'n duidelike beeld het van wat verwag word en ook oor die nodige kennis beskik om die uiting fonologies te beplan, maar nie altyd in staat is om dit korrek vooruit te voer vir produksie nie.

Die vervangings met eenheidskonsonante het meestal meegebring dat 'n besondere klank herhaal word in die eenheid. Guyard et al. [1981\} het dieselfde simptoom waargeneem by gevalle met Broca afasie en gepaardgaande verbale apraksie en hulle interpreteer dit as ' $n$ vereenvoudiging van die reeks. Die duplisering van klanke bring waarskynlik fonologiese en motoriese vereenvoudiging mee en dit is dus op grond van so ' $n$ verduideliking nie moontlik om die simptoom as ' $n$ motoriese of ' $n$ fonologiese probleem te klassifiseer nie.

Dit is belangrik om daarop te wys dat dit veral proefpersone 5 en 3 was wat vervangings vertoon het. In die geval van proefpersoon 5 kan die probleem moontlik verband hou met die feit dat hy ' $n$ verbale ontwikkelingsapraksie het en dat hy moontlik ' $n$ besondere probleem met volgordening van klanke het. Die simptome wat hy openbaar, stem egter heeltemal ooreen met die simptome van proefpersoon 3. Dieselfde tipe vervangings het by beide voorgekom. Proefpersoon 4 het ook dikwels vervangings vertoon terwyl dit selde voorgekom het by proefpersone 1 en 2 . Klankvervangings is dus nie ' $n$ kenmerkende simptoom van verbale apraksie nie_Indien-die-eorsprong daarvān $\overline{\text { wel }} \bar{s}^{-} \overline{\text { suiwer }}$ fonologies (dit wil sê linguisties-simbolies) is, impliseer die lae voorkoms daarvan $\{8,5 \%$ van alle foutel by slegs sommige verbaal apraktiese sprekers dat die fonologies gebaseerde simptome nie ' $n$ integrerende deel van verbale apraksie is nie.

Vervangings met nie-eenheidsklanke, wat moontlik op foutiewe seleksie van klanke dui, het in mindere mate as vervangings met eenheidsklanke voorgekom. Die hoogste frekwensie was ook by klankstrukture 3 en 5 . Hierdie vervangings kan ook as paradigmatiese foute beskryf word omdat dit foutiewe seleksie vanuit 'n interne "stoor" van foneme impliseer (Jakobson, 1971; Keller, 1978). Vanuit hierdie gesigspunt is vervangings met nie-eenheidsklanke suiwer fonologies gebonde probleme. Die besondere eise van die langer eenhede veroorsaak dat hierdie probleme intree.

'n Nadere ondersoek van die spesifieke klanke wat vervang word, werp egter ' $n$ ander lig op sommige van die vervangings met nie-eenheidskonsonante. Die $/ \mathrm{b} /$ is byvoorbeeld herhaaldelik vervang met $/ \mathrm{m} /$. Hierdie klanke is artikulatories verwant en die moontlikheid is nie uitgesluit dat die $/ \mathrm{m} /$ in werklikheid 'n distorsie in die produksie-eien. skappe van $/ \mathrm{b} /$ is nie. Die luisteraars het moontlik die klank dan as $n / m /$ geperseptueer.

Vokaalvervangings is ook by hierdie groep sprekers waargeneem. Dit bevestig die resultate van Keller (1978) wat ook vokaalvervangings by persone met Broca afasie en gepaardgaande verbale apraksie gevind het. Slegs nege vokaalvervangings met eenheidsklanke het voorgekom en sewe daarvan was by S5. Dit wil dus voorkom asof dit 'n ongewone verskynsel is by verbale apraksie en dat die persoon bewus is van die vokale in die uiting en die posisie daarvan. Die volgordening van konsonante is dus ' $n$ groter probleem.

Die vokaalvervangings met nie-eenheidsklanke was in die meeste gevalle vervangings van $/ \mathrm{i} / \mathrm{vir} / \mathrm{e} / \mathrm{en} / \mathrm{o} / \mathrm{vir} / \% / \mathrm{Op}$ pervlakkig beskou, dui dit op fonologiese seleksieprobleme, maar daar is ' $\mathrm{n}$ paar aanduidings dat 'n groot persentasie van hierdie vervangings in werklikheid die gevolg van probleme in motoriese programmering is. Daar is in die eerste plek waargeneem dat dieselfde vervangings by al die proefpersone voorgekom het. Dit impliseer dat 'n gemeenskaplike probleem of eienskap tot die simptoom aanleiding gee.

Vanuit die oogpunt van 'n gemerktheidsanalise dui bogenoemde vervangings op vereenvoudiging na laer gemerkte vokale (Keller, 1978). Die bewegings word dus sistematies vereenvoudig. Dit kan ook wees dat die artikulatoriese grense (ruimtelik en temporaal) tussen hierdie vokale nie streng afgebaken is deur die sprekers nie en dat geringe afwykings in die kritiese bewegingspesifikasies daartoe gelei het dat die luisteraars die afwykings as vervangings perseptueer terwyl dit in werklikheid ' $n$ vorm van distorsie is.

Die onkonstante aard van die vervangings dui ook daarop dat dit die gevolg is van klankdistorsie en waarskynlik weens 'n oorskryding van die kritiese artikulasiegrense tussen klanke. ' $\mathrm{n}$ Eenheid soos /dok $\varepsilon$ / is byvoorbeeld afwis-

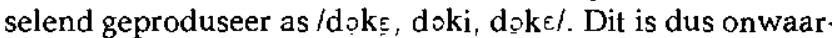
skynlik die gevolg van 'n afwyking in fonologiese klankseleksie.

Lettergreepvervangings-het-slegs-voorgekom by S3 en S5. Indien aanvaar word dat hierdie klankstrukture die moeilikste vir die verbaal apraktiese spreker is om te produseer, is lettergreepvervangings moontlik 'n ernstiger afwyking. Dit het egter selde voorgekom by die verbaal apraktiese sprekers.

Opsommend kom die resultate daarop neer dat klankvervangings wel voorkom by verbaal apraktiese sprekers, maar nie in dieselfde mate by almal nie. Die meeste vervangings kom voor by $\$ 5$ wat die langste klankstruktuur het. Dit wil dus voorkom asof vervangings konteks-sensitief is (Van der Merwe et al. 1987). Vervangings is egter nie ' $n$ prominente simptoom van verbale apraksie nie want slegs $8,5 \%$ van al die foute was klankvervangings. Die vervangings wat wel voorkom is waarskynlik nie weens 'n fonologiese beplanningsprobleem nie, want dit kom onkonstant voor tydens herhaalde produksie. Dit is ook nie weens 'n geheue- of fonologiese herroepings-probleem nie want die laaste van die herhalings was soms fonologies die mees korrekte. Dit wil wel voorkom asof daar ' $n$ probleem is in die onveranderlike vooruitvoering van foneme in die korrekte volgorde. Daar is veral ' $n$ neiging om konsonante te vervang met eenheidskonsonante wat dus ' $n$ afwyking in klankvolgorde is. Moontlik word die fonologiese en motoriese komponente van die produksie van die eenheid sodoende vereenvoudig. Vervangings met nie-eenheidskonsonante en vokale kom ook voor maar by ' $n$ nadere ondersoek van die artikulasieeienskappe van die spesifieke klanke blyk dit dat hierdie vervangings meer waarskyñlik distorsies van die doelwitklank is wat luisteraars perseptueer as vervangings.

\section{Verandering van struktuur van eenhede}

'n Totaal van $241\{9,6 \%\}$ foute is in hierdie foutkategorie aan. geteken. Die hoogste persentasie $\{38,2 \%\}$ foute het by S3 en S5 voorgekom (kyk tabel 2). Dit is interessant dat dieselfde. getal foute by altwee klankstrukture voorgekom het. Die gevolgtrekking dat die lengte van ' $n$ ' uiting nie die enigste faktor is wat die mate van afwyking bepaal nie (Van der Merwe et 
Tabel 2: Verandering van struktuur by die verskillende klankstruktuurgroepe

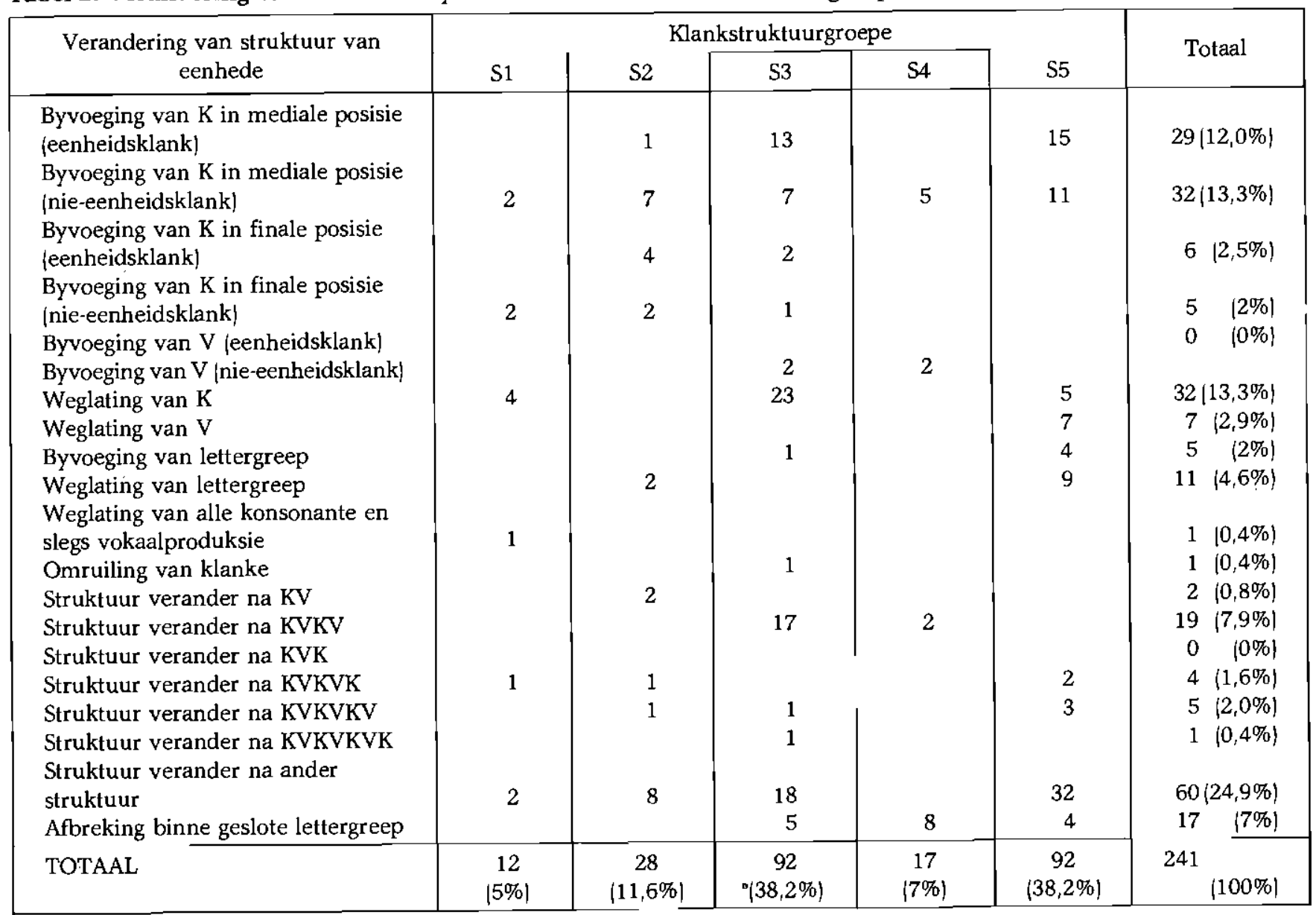

al. 1987) word dus deur hierdie analise bevestig. By S3 is die struktuur 17 keer vereenvoudig na 'n KVKV-struktuur en 18 veranderings na ander strukture soos veral 'n KVKKVKstruktuur het voorgekom. Dit wil dus voorkom asof die struktuur van S3 moeilik is vir die verbaal apraktiese spreker. Dit is waarskynlik so dat die herbeplande struktuur makliker vooruitgevoer kan word. Die verandering na 'n KVKV-struktuur is ondersteuning vir die teorie dat die KV-eenheid die natuurlike eenheid van spraakprogrammering is Jakobson, 1971: 21), maar die verandering na ' $n$ KVKKVK-struktuur is in opposisie met die teorie. Laasgenoemde is wel 'n duplisering van die KVK-eenheid wat min afwykings tot gevolg gehad het.

Die feit dat die klankstruktuur herbeplan en selfs verleng (KVKKVK is langer as KVKVK) word, dui daarop dat die sprekers wel die uiting fonologies en morfologies kan beplan en dus nie ' $n$ probleem het op hierdie vlak van beplanning nie. Die herbeplande uitings voldoen ook aan die fonotaktiese reëls van Afrikaans en Engels. Veranderinge in die klankstruktuur van 'n uiting moet dus nie sonder meer as ' $n$ afwyking in linguisties-simboliese beplanning beskou word nie. Dit is wel moontlik dat sodanige simptome so 'n afwyking kan weerspieël, maar binne die konteks van al die gedragspatrone van die sprekers, is so ' $n$ verklaring minder aanvaarbaar. Daar moet in gedagte gehou word dat hierdie sprekers verstaanbaar verbaal kan kommunikeer en dus die uitings linguisties kan beplan. Die produksie van die uitings is egter stadig en met hoorbare distorsie van die klankeienskappe.

Die klankstruktuur van $\mathbf{S 5}$ is in die meeste gevalle verkort deur byvoorbeeld die weglating van ' $n$ lettergreep (dit het nege keer voorgekom) of enkelklanke. Die struktuur is soms verleng en dit het meegebring dat dit in werklikheid moeiliker gemaak is. Geen strategieë om die uiting te vereenvoudig kan hierin gevind word nie en die indruk word gewek dat die spreker nie die eenheid kan onthou nie. In baie gevalle was die laaste herhalings egter nader aan die doelwituiting wat die moontlikheid aandui dat die kombinasie van foneme en/of die onveranderlike vooruitvoering daarvan problematies is by langer uitings.

' $n$ Verder interessante verskynsel is die afbreking binne geslote lettergrepe wat by S3, S4 en S5 voorgekom het. Die redenasie kan moontlik geopper word dat dit eerder as afwykings in temporale vloei geklassifiseer moet word. Dit was egter die afbakening van lettergrepe binne die uiting wat verander is. Die KVK-eenhede is byvoorbeeld verander na KV-K en die KVKVK-eenhede na KVKV-K. Hierdie verskynsel dui ook daarop dat die vooruitvoering van ' $\mathrm{n} K \mathrm{KV}$-, of KVKV-eenheid wat 'n duplisering is, makliker of meer natuurlik is en dat die uiting sodoende vereenvoudig word.

Verandering van struktuur het by al die proefpersone voorgekom, maar daar was individuele gedragspatrone wat baie interessante inligting aan die lig gebring het. Proefpersoon 2 het 'n feitlik konstante getal foute by al die strukture vertoon behalwe by $\mathrm{S} 4$ waar daar minder was. Proefpersone 3 en 5 het dieselfde tipe foute vertoon en beide het veral by S3 en S5 foute gemaak. Proefpersoon 1 het onverwags by $\mathrm{S} 4$ foute vertoon en proefpersoon 4 het geen foute gemaak nie.

Die huidige data wat verkry is, kan slegs in beperkte mate met die bevindinge van ander navorsers vergelyk word. La 
Pointe en Johns $\{1975\}$ het ook klankvolgordefoute waargeneem. Preposisionering van klanke in ' $n$ woord is in beide ştudies gevind. Hierdie navorsers en ook Trost en Canter (1974) vind dat metatese feitlik nooit voorkom nie. Dit bevestig die huidige resultate want slegs een geval hiervan is waargeneem (kyk tabel $2-$ Omruiling van klanke). Hulle bevind ook dat slegs ' $n$ klein persentasie van die foute van verbaal apraktiese sprekers, klankvolgordefoute is. Die data van hierdie ondersoek is nie op presies dieselfde wyse en met dieselfde doel ontleed as die data van La Pointe en Johns \{1975\} nie en verdere vergelykings is nie sonder verdere ontleding van die versamelde data moontlik nie.

Hierdie resultate kom dus daarop neer dat die klankstruktuur van 'n uiting wel ' $n$ invloed het op frekwensie en tipe veranderinge in die struktuur van die uiting. Die grootste getal veranderinge in klankstruktuur het voorgekom by S3 en S5. Enkele van die simptome soos die verlenging van die struktuur van $S 5$ kan as ' $n$ probleem in fonologiese beplanning beskou word. Die ander simptome soos die sistematiese vereenvoudiging van S3- en S5-eenhede dui daarop dat die sprekers wel in staat is tot fonologiese herbeplanning van die uiting en kennis het van fonotaktiese reëls. Die verbaal aprak tiese sprekers ondervind moontlik 'n probleem in algemene motoriese beplanning en sistematiese vooruitvoering en verander die struktuur dan na ' $n$ vorm wat makliker geproduseer kan word. Hierdie vorm stem ooreen met die sogenaamde eenheid van spraakprogrammering (volgens die meeste teoretici) naamlik die KV-lettergreep of 'n duplisering daarvan.

\section{Distorsie}

Die voorkoms van die verskillende vorms van distorsie by die verskillende klankstrukture word aangegee in tabel 3 . Distorsie het yoorgekom by al die klankstrukture en die persentasie van voorkoms verskil nie baie nie. Die hoogste per sentasie is $26,6 \%$ by $\mathrm{S} 1$ en die laagste is $14,3 \%$ by $\mathrm{S} 4$. Dit wil dus voorkom asof die klankstruktuur van 'n uiting nie 'n groot rol speel by die voorkoms van distorsie nie. Distorsie is waarskynlik ' $n$ kenmerkende simptoom van verbale apraksie wat voorkom ongeag die eienskappe van die uiting. aangeteken. 'n Klankvervanging is ook aangeteken indien 'n klank vervang is met ' $n$ klank wat artikulatories onverwant is daaraan. Die onderskeid tussen distorsie en klankvervangings is egter soms ' $n$ probleem. Geen vorige navorsing is hieroor gedoen wat as riglyn gebruik kan word nie. Elektromiografiese, spektrografiese en ander metodes wat spraakbewegings kan ontleed, moet in die toekoms gebruik word om distorsie by verbale apraksie na te vors.

Die vorm van distorsie met die hoogste voorkoms is versteuring van stemhebbendheid wat meebring dat 'n klank nie met sekerheid herken word as stemhebbend of stemloos nie. Hierdie resultaat van die ouditiewe analise bevestig dat die onvermoë tot interartikulator-sinchronisasie (tussen die glottis en artikulasiestrukture) vir korrekte stemgewing een van die prominentste en kenmerkendste probleme van die verbaal apraktiese spreker is.

Die syfers in tabel 3 toon aan dat meer foute in stemhebbendheid van klanke by $\mathrm{S} 1, \mathrm{~S} 4$ en $\mathrm{S} 2$ voorkom as by die ander strukture wat andersins meer probleme tot gevolg gehad het. Die moontlikheid bestaan dat die sprekers poog om stemhebbendheid te beheer en dat die poging toeneem in intensiteit by die moeiliker en langer uitings. Dit bring dan mee dat minder SAT-foute voorkom by die langer en moeiliker klankstrukture.

Ander vorms van konsonantdistorsie het ook voorgekom en het $20,3 \%$ van die distorsiefoute uitgemaak. Die meeste van hierdie foute het voorgekom by S3 en S5. Die langer uitings bevat meer klanke wat foutief geproduseer kan word, maar dit het ook die /f/-klank bevat wat baie van die foute tot gevolg gehad het. Vorige navorsers het ook bevind dat frikatiewe moeilik is vir verbaal apraktiese sprekers [Shankweiler en Harris, 1966; La Pointe en Johns, 1975; Trost en Canter, 1974; Wertz et al. 1984: 52). Dit is dus 'n kombinasie van faktore wat meebring dat meer konsonantdistorsies voorkom by $\mathrm{S} 3$ en S5. Dit is interessant dat S3 ook in hierdie geval meer foute meebring as S5. Die lengte van die eenheid is dus ook met betrekking tot die getal konsonantdistorsies nie die enigste bepalende faktor nie.

Tabel 3: Distorsie by die verskillende klankstruktuurgroepe:

\begin{tabular}{|c|c|c|c|c|c|c|}
\hline \multirow[b]{2}{*}{$\begin{array}{l}\text { Klankstruk- } \\
\text { tuurgroepe }\end{array}$} & \multicolumn{5}{|c|}{ Distorsiefoute } & \multirow[b]{2}{*}{ Totaal } \\
\hline & $\begin{array}{l}\text { Stemheb- } \\
\text { bendheid }\end{array}$ & $\begin{array}{c}\text { Konsonant } \\
\text { - ander }\end{array}$ & Vokaal & $\begin{array}{l}\text { Verandering } \\
\text { van vokaal- } \\
\text { eienskappe }\end{array}$ & $\begin{array}{l}\text { Lettergreep } \\
\text { of eenheid }\end{array}$ & \\
\hline S1 & 127 & 7 & 62 & 9 & 0 & $205(26,6 \%)$ \\
\hline $\mathrm{S} 2$ & 55 & 18 & 50 & 4 & 1 & $128(16,7 \%)$ \\
\hline S3 & 44 & 67 & 48 & 5 & 5 & $169 \quad(22 \%)$ \\
\hline S4 & 64 & 12 & 32 & 2 & 0 & $110(14,3 \%)$ \\
\hline S5 & 35 & 52 & 64 & 2 & 4 & $157(20,4 \%)$ \\
\hline Totaal & $325[42,2 \%]$ & $156(20,3 \%)$ & $256\{33,3 \%\}$ & $22\{2,9 \%\}$ & $10\langle 1,3 \%)$ & $769\{100 \%\}$ \\
\hline
\end{tabular}

Die distorsies wat waargeneem is tydens die ondersoek het onkonstant voorgekom. 'n Besondere klank of meer klanke binne ' $n$ uiting is soms tydens die herhaalde produksies foutief geproduseer. Die mate van distorsie het ook gevarieer. Die verandering in die klankeienskappe was soms net waarneembaar terwyl dit by 'n volgende herhaling soms in so ' $n$ mate afgewyk het dat dit byna soos 'n klankvervanging geklink het. In sommige gevalle, wanneer die klank suiwer en vlot geproduseer is, is klankvervangings wel as sodanig
Distorsie van vokale het $33,3 \%$ van al die distorsiefoute uitgemaak. Dit het by al die klankstrukture voorgekom. Die laer voorkoms van vokaaldistorsie teenoor konsonantdistorsie bevestig die résultate van Shankweiler en Harris \{1966). Distorsie is onderskei van veranderinge in die vokaaleienskappe $[2,9 \%)$ wat in werklikheid ' $n$ ' vorm van diftongisering was. In laasgenoemde geval is daar moontlik ' $n$ onvermoë om die kritiese artikulatoriese konfigurasie te behou of om stemgewing en/of tongbeweging te onderbreek terwyl 
daar na die posisie van die volgende klank beweeg word. Die ander vorms van vokaaldistorsie is moontlik weens ' $n$ onvermoë om die kritiese ruimtelike konfigurasie te bereik.

Distorsie van 'n lettergreep en eenheid het slegs $1,3 \%$ van die totale aantal distorsies uitgemaak en was met 'n enkele uitsondering beperk tot S3 en S5. Distorsie van enkele klanke binne ' $n$ uiting is dus die meer algemene verskynsel by verbale apraksie.

'n Teorie wat die verskynsel van distorsie by verbale apraksie verklaar, moet ook die feit verklaar dat slegs enkele klanke binne ' $n$ uiting aangetas word, dat hierdie aantasting onkonstant plaasvind en dat meer distorsie voorkom by uitings met ' $n$ besondere klankstruktuur.

Die mees algemene oorsaak vir klankdistorsie is spiertonusen spierkoördinasieprobleme soos wat voorkom by disartrie (Darley et al. 1975; Itoh en Sasanuma, 1984). Soortgelyke probleme is nie waargeneem by verbaal apraktiese sprekers nie (Shankweiler en Harris, 1966) en kan dus nie die voor. koms van distorsie verklaar nie.

Die moontlikheid dat klankdistorsie by verbale apraksie deur een of ander vorm van 'n perseptuele probleem veroorsaak word, behoort ook oorweeg te word. Dit is egter nie duidelik hoe ' $n$ ouditiewe of oraal-sensoriese terugvoeringsen/of persepsieprobleem of selfs ' $n$ interne terugvoerings probleem tot onkonstante distorsie van klanke kan aanlei. ding gee nie. Dit is meer waarskynlik dat 'n perseptuele en terugvoeringsprobleem konstant teenwoordig sal wees ( en 'n konstante probleem veroorsaak) en nie sensitiwiteit vir kontekstuele faktore sal vertoon nie. Die konteks van 'n uiting soos byvoorbeeld die klankstruktuur het wel implikasies vir die beplanning en produksie van spraak. Reaksie op die konteks en in hierdie geval die voorkoms van distorsie, is dus meer waarskynlik ' $n$ aanduiding dat distorsie voorkom weens ' $n$ versteuring in die beplanning en/of produksie van spraak.

Die verlies van die ouditiewe beeld van die kritiese akoes-

tiese konfigurasie van ' $n$ klank is ' $n$ meer aanneemlike verklaring as 'n terugvoerings- of perseptuele probleem, maar dit sou waarskynlik ook aanleiding gee tot 'n konstant teenwoordige probleem. Dit behoort ook nie konteks-sensitiwiteit te vertoon nie.

Itoh en sy medewerkers $(1979,1984)$ wat die eerste navorsers was wat distorsie by verbale apraksie as ' $n$ eienskap van verbale apraksie in die literatuur beskryf het, beskou distorsie as die gevolg van temporale wansinchronisasie tussen die bewegings van verskillende artikulators. Dit is wel ' $\mathrm{n}$ redelike verklaring vir die aspek wat hulle ondersoek het, naamlik die temporale wansinchronisasie van velêre en ander artikulasiebewegings. Dit lei dan tot ontoepaslike nasalering of denasalering van klanke en soms gevolglike foutiewe identifikasie van klanke. Dit is egter ook moontlik dat ruimtelike faktore tot distorsie aanleiding gee. Soos reeds aangedui, vereis akkurate spraakproduksie dat die kritiese ruimtelike konfigurasie by herhaling bereik moet word en dat die natuurlike mate van ekwivalensie (Hughes \& Abbs, 1976) nie oorskry word nie. Sekere klanke is ruimtelik baie naby verwant en die oorskryding van die kritiese ruimtelike ekwivalensiegrense kan meebring dat daar distorsie van die klank is of selfs dat dit as 'n ander klank waargeneem word. Tydens die ondersoek is waargeneem dat die mate van distorsie voortdurend wissel. Die kritiese grense van ekwivalensie is dus telkens in wisselende mate oorskry. Hierdie grense is dus te plasties by die verbaal apraktiese spreker.

Opsommend kom die resultate daarop neer dat die klankstruktuur van 'n uiting nie 'n groot rol speel by die voorkoms van distorsie nie. Die vorm van distorsie met die hoog. ste voorkoms is versteurings van stemhebbendheid. Minder vokaaldistorsies as konsonantdistorsies is waargeneem. Distorsie kom onkonstant by herhaling van dieselfde uiting voor. Die mate van distorsie varieer ook. Hierdie feite en ook die feit dat konteks-sensitiwiteit wel voorkom, lei tot die afleiding dat distorsie voor kom weens ' $n$ probleem in die beplanning van die temporale en ruimtelike dimensies van beweging. Die kritiese ekwivalensiegrense word dan telkens in wisselende mate oorskry.

\section{Afwykings in temporale vloei}

Die aspekte wat geklassifiseer is as afwykings in temporale vloei het te doen met die ouditief waarneembare tempo van vooruitvoering van spraak.

Ongeveer dieselfde persentasie afwykings in temporale vloei is waargeneem by S1, S2, S3 en S5 terwyl S4 baie minder foute vertoon (kyk tabel 4). In die produksie van S4 is die vokale, soos reeds met die akoestiese analises bevind, selde en minimaal verleng en afbakening in lettergrepe is minder waarskynlik. Dit is interessant dat S5 minder foute opgelewer het as S1, S2 en S3. Daar is waargeneem dat die proefpersone die eenhede in S5 ritmies geproduséer het en moontlik het die inherente ritme van hierdie klankstruktuur temporale vloei gefasiliteer.

Tabel 4: Afwykings in temporale vloei by die verskillende klankstruktuurgroepe

\begin{tabular}{|c|c|c|c|c|c|c|}
\hline \multirow[b]{2}{*}{$\begin{array}{l}\text { Klankstruk- } \\
\text { tuurgroepe }\end{array}$} & \multicolumn{6}{|c|}{ Afwykings in temporale vloei } \\
\hline & $\begin{array}{l}\text { Verlenging } \\
\text { van vokaal }\end{array}$ & $\begin{array}{c}\text { Verlenging } \\
\text { van konso- } \\
\text { sonant }\end{array}$ & $\begin{array}{l}\text { Artikulasie- } \\
\text { verlenging }\end{array}$ & $\begin{array}{c}\text { Stadige doel- } \\
\text { bewuste } \\
\text { artikulasie }\end{array}$ & $\begin{array}{l}\text { Lettergrepe } \\
\text { kom afge- } \\
\text { bakend voor }\end{array}$ & Totaal \\
\hline S1 & 48 & 0 & 32 & 6 & 127 & $213\{23,9 \%\}$ \\
\hline S2 & 39 & 7 & 32 & 4 & 124 & $206(23,1 \%)$ \\
\hline S3 & 49 & 22 & 32 & 0 & 120 & $223 \quad[25 \%]$ \\
\hline $\mathrm{S} 4$ & 15 & 22 & 21 & 4 & 2 & $64 \quad(7,1 \%)$ \\
\hline S5 & 22 & 1 & 32 & 8 & 123 & $186\{20,9 \%\}$ \\
\hline Totaal & $173(19,4 \%)$ & $52\{5,8 \%\}$ & $149(16,7 \%)$ & $22\{2,5 \%\}$ & $496(55,6 \%)$ & $892(100 \%)$ \\
\hline
\end{tabular}


Die verlenging van vokale het $19,4 \%$ van die totale getal af wykings in temporale vloei uitgemaak in teenstelling met $5,8 \%$ verlengings van konsonante. Volgens Crompton (1980) is die duur van vokale meer veranderlik en die verbaal apraktiese sprekers was meer geneig om dit te verleng. Die konsonante wat wel verleng is, is in S3 en S4. 'n Nadere ondersoek van die data bring ' $n$ baie interessante verskynsel aan die lig. Die vier sprekers met vérworwe verbale apraksie het almal die finale konsonant van die KVK-eenhede (S4) en die tweede konsonant in KVKVK- (S3) eenhede verleng (in gevalle waar verlenging wel voorgekom het). Die feit dat dieselfde verskynsel by die vier proefpersone voor. kom, impliseer dat die beplanning en vooruitvoering van hierdie klankstrukture sekere eise stel wat op dieselfde wyse oorkom is. Die verlenging van die finale konsonant by $\mathrm{S} 4$ is verrassend want oor die algemeen het die minste foute by hierdie klankstruktuur voorgekom. Daar moet egter in gedagte gehou word dat die eenhede agtereenvolgend geproduseer is en moontlik is die finale klank verleng terwyl die volgende uiting beplan is. Die KVKVK-struktuur kan verdeel word in ' $\mathrm{n}$ KVK- en VK-gedeelte en in hierdie geval is dit ook soos by die KVK-eenhede, die tweede konsonant wat verleng is. Die vraag ontstaan of dit nie die besondere klank is wat aanleiding gee tot verlenging nie. Klankstrukture 2 en 5 bevat egter ook die klanke wat verleng is $[/ \mathrm{k} /$ en $/ \mathrm{t} /\}$ maar by hierdie strukture vind verlenging baie minder (sewe en een keer) plaas. Die besondere klankstruktuur van S3 en S4 is dus die faktor wat aanleiding gee tot die verlenging van konsonante.

Die artikulasieverlenging wat waargeneem is, verwys in hierdie studie na verlenging van alle klanke. Dit het net by proefpersoon 4 voorgekom. Akoestiese analises (Van der Merwe, 1986) het aan die lig gebring dat die duur van die uiting in mindere mate afwyk as vokaalduur. By hierdie persoon is die oorgange tussen klanke en dus die spoed van vooruitvoèring nie stadiger as by die ander proefpersone nie, maar die statiese periode van artikulasie is verleng. Die verlenging het minimale sensitiwiteit vir klankstruktuur vertoon en is dus 'n konstante verskynsel wat ook blyk uit die 32 foute by S1, S2, S3 en S5. Hierdie simptoom is moontlik die gevolg van die besondere letsel van proefpersoon 4 , naamlik in die linkerperifere pariëtale gebied en in die posterior-been van die capsula interna wat onder meer deel uitmak van die afferente sensoriese bane na die talamus en van die basale ganglia (Chusid, 1973: 13; 153-159). Sensoriese terugvoering tydens spraak is moontlik as gevolg van dié letsel onvoldoende en die persoon kompenseer deur segmentele duur te verleng. So ' $n$ verklaring is aanvaarbaar indien aanvaar word dat sensoriese terugvoering nodig is vir spraakvorming of vir die beheer van spraak onder buitengewone omstandighede soos 'n programmeringsprobleem.
Stadige doelbewuste artikulasie het voorgekom by proefpersone 2 en 3 en is slegs 22 keer waargeneem. Stadige doelbewuste artikulasie is ' $n$ subjektiewe waarneming deur ' $n$ luisteraar in teenstelling met die ander foute wat ouditief duidelik identifiseerbaar is. Om ' $n$ werklik akkurate beskrywing daarvan te gee en om die verskil hiertussen en artikulasieverlenging te bepaal, sal 'n spektrografiese ontleding van groot waarde wees. Proefpersoon 3 het ook afwykings in inisiëring vertoon en dit is moontlik dat die stadige doelbewuste artikulasie ' $n$ minder ernstige simptoom is van ' $n$ inisiëringsafwyking wat daartoe lei dat die spoed van vooruitvoering stadig is. Dit kan ook 'n kompensatoriese reaksie wees op die algemene probleem in programmering.

Die grootste afwyking in temporale vloei is die afbakening van lettergrepe en dit het by al die proefpersone voorgekom en by al die eenhede met meer as een lettergreep. Dit is wel twee keer waargeneem by $\$ 4$ waar proefpersoon 1 die eenheid tydens twee van die vier herhalings geproduseer het as (du - k/. Die afbakening van lettergrepe is ook deur vorige navorsers (Kent en Rosenbek, 1982 en 1983; Trost en Canter, 1974) waargeneem. Kent en Rosenbek (1982) spreek die mening uit dat hierdie simptoom 'n aanduiding is dat die be. planning van spraak in onafhanklike lettergreep-eenhede plaasvind omdat die spreker nie groter eenhede kan hanteer nie. Lettergreepvooruitvoering vind dus plaas. Dit is 'n logiese verklaring vir die simptoom, maar die vraag ontstaan of die eenhede werklik onafhanklik beplan is en of slegs die vooruitvoering en produksie in lettergreep-eenhede plaasvind. Deur die voorkoms van koartikulasie en adaptasie by die klankomgewing na te gaan, sal moontlik 'n antwoord op hierdie vraag verkry word.

Hierdie resultate dui dus daarop dat ver skillende vorms van afwykings in temporale vloei voorkom en dat die meeste hiervan nie sensitiwiteit vir die klankstruktuur van die uiting vertoon nie. Die verlenging van konsonante het wel meer probleme met die vooruitvoering van S3 en 54 uitgelig. Die het net by die sprekers met verworwe verbale apraksie voorgekom. Die resultate toon aan dat sekere simptome (soos artikulasieverlenging) meer individueel is terwyl ander' (soos die afbakening van lettegr epe en vokaalverlenging) by al die sprekers voorkom. Kent en Rosenbek (1983) het ook individuele variasie in die vorms van temporale ver. steuring waargeneem. Die algemene indruk is dat die waarneembare simptome waarskynlik kompensatoriese aksies in reaksie op ' $n$ onderliggende probleem in die motoriese programmering van spraak is.

\section{Afwykings in vlotheid}

Probleme om spraak te inisieer word as een van die ken-

Tabel 5: Afwykings in vlotheid by die verskillende klankstruktuurgroepe

\begin{tabular}{|c|c|c|c|c|c|}
\hline \multirow[b]{2}{*}{$\begin{array}{l}\text { Klankstruk- } \\
\text { tuurgroepe }\end{array}$} & \multicolumn{5}{|c|}{ Afwykings in vlotheid } \\
\hline & $\begin{array}{c}\text { Onvlot } \\
\text { herhaling }\end{array}$ & $\begin{array}{l}\text { Vassteking } \\
\text { (bv. glottale } \\
\text { afsluiting) }\end{array}$ & $\begin{array}{c}\text { Vassteking } \\
\text { met hoorbare } \\
\text { worstelgedrag }\end{array}$ & $\begin{array}{c}\text { Stadige } \\
\text { worstelende } \\
\text { artikulasie }\end{array}$ & Totaal \\
\hline S1 & 2 & 4 & 1 & 5 & $12(10,1 \%)$ \\
\hline $\mathrm{S} 2$ & 2 & 5 & 8 & 8 & $23(19,5 \%)$ \\
\hline S3 & 4 & 9 & 6 & 8 & $27(22,9 \%)$ \\
\hline $\mathrm{S} 4$ & 1 & 2 & 1 & 15 & $19\{16,1 \%\}$ \\
\hline S5 & 8 & 11 & 9 & 9 & $37\{31,4 \%\}$ \\
\hline Totaal & $17(14,4 \%)$ & $31\{26,3 \%\}$ & $25\{21,2 \%]$ & $45(38,1 \%)$ & $118(100 \%)$ \\
\hline
\end{tabular}


merkendste eienskappe van verworwe verbale apraksie beskryf (Wertz et al. 1984; Kent en Rosenbek, 1983; Collins et al. 1983\}. Volledige simptoombeskrywings word egter nie verskaf nie. Wertz et al. (1984: 76) sê wel dat probleme in inisiëring gekenmerk word deur "false starts and restarts".

In die huidige ondersoek is vier tipes simptome waargeneem wat geklassifiseer kan word as afwykings in vlotheid (kyk tabel 5). Die simptome kan ook beskryf word as afwykings in inisiëring. Stadige worstelende artikulasie wat die grootste persentasie $\{38,1 \%\}$ van die totale aantal afwykings in vlotheid uitmaak, het slegs by proefpersoon 3 voorgekom. Die meeste van die foute in die ander drie subkategorieë is ook gemaak deur proefpersoon 3. Die afwykings in vlotheid het slegs $4,7 \%$ van die totale aantal foute uitgemaak en is skynbaar nie ' $n$ tipiese probleem van die groep verbaal apraktiese sprekers nie. Dit is moontlik dat hierdie sprekers anders sal reageer in spontane spraak.

Die meeste afwykings in vlotheid het voorgekom by S3 en S5. Rosenbek (1980) sê ook dat meer afwykings in vlotheid by langer eenhede voorkom. 'n Interessante verskynsel is dat proefpersoon 3 meer gevalle van stadige worstelende artikulasie by $\mathrm{S} 4$ as by die ander klankstrukture vertoon het. Die data is nagegaan vir enige tendense wat hierdie verskynsel kan verklaar. Die enigste moontlike verklaring is dat die vooruitvoering van die KVK-struktuur moontlik moeilik is omdat dit nie die natuurlike eenheid van programmering is nie.

Daar is verskillende moontlike oorsake vir die herhalings, vasstekings en worstelende artikulasie wat by verbale apraksie voorkom. Daar kan 'n onvermoë wees om die bewegings temporaal te orden en vooruit te voer of sensoriese te. rugvoering en interne terugvoering kan moontlik swak gekoördineer word met programmering. Dit kan ook 'n ware inisiëringsprobleem wees en die spreker is dan nie in staat om te begin beweeg nie. Laasgenoemde word soms beskryf as ' $n$ ideomotoriese apraksie (Rosenbek, 1980).

Opsommend kom die resultate daarop neer dat daar aanduidings is dat vlotheid en inisiëring wel in ' $n$ mate kontekssensitief is. Meer afwykings in vlotheid het by die langer uitings, naamlik S3 en S5! voorgekom en proefpersoon 3 het meer stadige worstelendé artikulasie by die KVK-struktuur vertoon. Die verbaal apraktiese sprekers vertoon nie in dieselfde mate afwykings in vlotheid nie.

\section{Spraakfoute gevolg deur selfkorreksie}

Spraakfoute gevolg deur selfkorreksie het meer by $\$ 5$ en $\$ 3$ as by die ander klankstrukture voorgekom (kyk tabel 6 ) en dit was teenwoordig by al die proefpersone/behalwe by proefpersoon 1. Dit was slegs verbetering van klankseleksiefoute wat voorgekom het en proefpersoon 1 het baie min hiervan vertoon.

Ongeveer dieselfde getal klankveranderinge en lettergreepveranderinge het voorgekom. In die geval van klankveranderinge was dit meestal suksesvol en by lettergreepveranderinge meestal onsuksesvol. Die feit dat klank- en lettergreepveranderinge voorgekom het, dui daarop dat die verbaal apraktiese sprekers bewus is van foutiewe klankseleksie en poog om dit te verbeter. Dit was ook die geval by proefpersoon 5. Dit is opvallend dat geen ander vorms van selfkorreksie, byvoorbeeld van distorsies, voorgekom het nie. Die sprekers is dus nie bewus van die groot getal distorsiefoute nie of is bewus van hul onvermoë om dit te verbeter. In ' $n$ sekere sin bevestig hierdie bevindinge die standpunt van Itoh en Sasanuma (1984) dat distorsie die kernsimptoom van verbale apraksie is. Selfkorreksie by verbaal apraktiese sprekers is nog nie formeel ondersoek nie en net beperkte vergelykings met ander studies kan getref word. Deal en Darley \{1972\} het wel die vermoë om foute te voorspel by verbaal apraktiese sprekers nagegaan en gevind dat hulle daartoe in staat is, maar dat meer foute gemaak word as wat voorspel is. Die proefpersone was ook in staat om sommige van hul foute te herken.

\section{Afwykings in prosodie}

Afwykings in prosodie verwys in hierdie studie net na simptome soos oormatige of afwykende klem- en intonasiepatrone en momentele afwykende stemkwaliteit. Afwykings in prosodie is ook deur ander navorsers waargeneem (Kent en Rosenbek; 1982, 1983). Dit word beskryf as disprosodie en verwys in besonder na stadige spraakspoed, verlengde segmentele duur en lettergreep-afbakening. Hierdie aspekte is in hierdie ondersoek afsonderlik bestudeer.

Tabel 7: Afwykings in prosodie by die verskillende klankstruktuurgroepe

\begin{tabular}{|l|c|c|c|c|c|c|}
\hline \multirow{7}{*}{} & \multicolumn{5}{|c|}{ Klankstruktuurgroep } & \multirow{2}{*}{ Totaal } \\
\cline { 5 - 6 } & S1 & S2 & 53 & S4 & S5 & \\
\hline $\begin{array}{l}\text { Aantal } \\
\text { foute }\end{array}$ & 53 & 57 & 48 & 46 & 38 & 242 \\
\cline { 6 - 7 } & $(21,9 \%)$ & $\{23,6 \%\}$ & $(19,8 \%)$ & $(19 \%)$ & $\{15,7 \%\}$ & $(100 \%)$ \\
\hline
\end{tabular}

Tabel 6: Spraakfoute gevolg deur selfkorreksie by die verskillende klankstruktuurgroepe

\begin{tabular}{|c|c|c|c|c|c|}
\hline \multirow{3}{*}{$\begin{array}{l}\text { Klankstruk- } \\
\text { tuurgroepe }\end{array}$} & \multicolumn{5}{|c|}{ Spraakfoute gevolg deur selfkorreksie } \\
\hline & \multicolumn{2}{|c|}{ Klankverandering } & \multicolumn{2}{|c|}{ Lettergreepverandering } & \multirow{2}{*}{ Totaal } \\
\hline & Suksesvol & Onsuksesvol & Suksesvol & Onsuksesvol & \\
\hline S1 & 1 & 0 & 1 & 2 & $4(12,5 \%)$ \\
\hline S2 & 2 & 1 & 1 & 1 & $5\{15,6 \%\}$ \\
\hline S3 & 3 & 0 & 2 & 3 & $8 \quad(25 \%)$ \\
\hline S4 & 0 & 0 & 1 & 0 & $1\{3,1 \%\}$ \\
\hline S5 & 6 & 2 & 2 & 4 & $14(43,8 \%)$ \\
\hline Totaal & $12(37,5 \%)$ & $3(9,4 \%)$ & $7(21,9 \%)$ & $10\langle 31,2 \%)$ & $32(100 \%)$ \\
\hline
\end{tabular}


Die prosodiese aspekte wat in hierdie studie nagegaan is, is nog slegs in beperkte mate deur andere ondersoek. Kent en Rosenbek (1983) het wel op grond van spektrografiese analises waargeneem dat daar min variasie in piekintensiteit oor ' $n$ antal lettergrepe by verbaal apraktiese sprekers is. Die beoordeling van diê aspek in hierdie studie was nie in soveel diepte nie. Daar is wel waargeneem dat die afwyking in prosodie dikwels vererger het wanneer die proefpersoon die uiting by herhaling korrek kon sê. Prosodiefoute het, afgesien van ' $n$ enkele uitsondering by proefpersoon 1 , slegs by proefpersoon 2, 3 en 4 voorgekom en glad nie by proefpersoon 5 nie.

Die afwykings in prosodie het by al die klankstrukture voorgekom (kyk tabel 7). Dit is dus 'n konstant teenwoordige probleem wat nie konteks-sensitief is nie. Dit wil voorkom asof alle afwykings in prosodie nie by alle verbaal apraktiese sprekers voorkom nie. Hierdie probleme moet egter met akoestiese tegnieke ondersoek word alvorens enige betroubare afleidings gemaak kan word.

\section{GEVOLGTREKKINGS}

Die resultate van hierdie ondersoek dui daarop dat verbale apraksie 'n afwyking is wat gekenmerk word deur:

- distorsie van klanke wat soms soos vervangings van klanke klink;

- afwykings in temporale vloei met veral die afbakening van lettergrepe en verlenging van klanke:

- /veranderinge in die struktuur van ' $n$ eenheid met veral ' $n$ neiging om dit te vereenvoudig na ' $\mathrm{KV}$-eenheid of dupliséring daarvan;

- yervangings met eenheidsklanke van veral konsonante;

- afwykings in die vlotheid van spraak;

pogings tot selfkorreksie van klankvervangings; en

$\frac{T}{t}$ afwykings in die prosodiese eienskappe van spraak;

Al die simptome kom nie in dieselfde mate by al die-verbaal apraktiese sprekers voor nie.

'n Verdeling van die simptome op grond van konteks-sensitiwiteit dui daarop dat distorsie van klanke, lettergreepafbakening en ook onkonstantheid in produksie, kernprobleme van verbale apraksie weerspieël. Vervangings, byvoegings en weglatings wat konteks-sensitief is, is moontlik geassosieerde simptome en kompensatoriese strategieë om die kompleksiteit van 'n uiting te verminder.

Dit wil voorkom asof die verbaal apraktiese spreker 'n onderliggende onvernoë het om konstant die kritiese temporale en ruimtelike ewivalensiegrense van spraakbewegings te bereik, spraakklanke vinnig en onveranderlik vooruit te voer en om spraakuitings wooruit te beplan. Die verbaal apraktiese spreker is wel bewus van sy probleem en poog om die spraakuitings te vereenvoudig.

Die resultate van hierdie ondersoek dui verder ook daarop dat verbale apraksie voorkom na verworwe breinskade, maar dat ' $n$ aangebore onvermoë om spraak te beplan, wel ook kan bestaan.

\section{ERKENNINGS}

Geldelike bystand van die Raad van Geesteswetenskaplike Navorsing vir hierdie ondersoek, word hiermee erken.

\section{VERWYSINGS}

Aten, J.L., Darley, F.L., Deal, J.L. en Johns, D.F. Comment on A.D Martin's "Some objections to the term apraxia of speech". Journal of Speech and Hearing Disorders, 40, 416-420, 1975.

Buckingham, H.W. Explanation of apraxia with consequences for the concept of apraxia of speech. Brain and Language, 8 , 202-226, 1979 .

Chusid, J.G. Correlative Neuroanatomy and Fanctional Neurology, 15de uitgawe, Los Altos, California: Lange Medical Publications 1973.

Collins, M., Rosenbek, J.C. en Wertz, R.T. Spectrographic analysis of vowel and word duration. Joumal of Speech and Hearing Research, 26, 224-230, 1983.

Crompton, A. Timing patterns in French. Phonetica, 37, 205-234, 1980.

Darley, F.L., Aronson, A. en Brown, J. Motor Speech Disorders. Philadelphia: Saunders, 1974.

Deal, J.L. en Darley, F.L. The influence of linguistic and situational variables on phonemic accuracy in apraxia of speech. Journal of Speech and Hearing Research, 15, 639-653, 1972.

Dunlop, J.M. en Marquardt, T.P. Linguistic and articulatory aspects of single word production in apraxia of 'speech. Cortex, 13, 17-29, 1977.

Edwards, M.L. en Shriberg, L.D. Phonology: Applications in communi cative disorders. California: College-Hill Press, 1983.

Guyard, H., Sabouraud, O. \& Gagnepain, J. A procedure to differentiate phonological disturbances in Broca's aphasia and Wernicke's aphasia. Brain and Language, 13, 19-30, 1981.

Hughes, O.M. en Abbs, J.H. Labial-mandibular coordination in the production of speech: Implications for the operation of motor equivalence. Phonetica, 33, 199-221, 1976.

Itoh, M., Sasanuma, S. en Ushijima, T. Velar movements during speech in a patient with apraxja of speech. Brain and Language. $7,227-239,1979$

Itoh, M. en Sasanuma, S. Articulatory movements in apráxia of speech. In J.C. Rosenbek, M.R. McNeil en A.E. Aronson (Reds.) Apraxia of Speech: Physiology, Acoustics, Linguistics, Management. California: College-Hill Press, 1984:

Jakobson, R., Fant, C.G.M. en Halle, M. Preliminaries to speech analysis. Massachusets: MIT Press, 1967.

Jakobson, R. Studies on child language and aphasia. Paris: Mouton, 1971.

Johns, D.F. en Darley, F.L. Phonemic variability in apraxia of specch. Journal of Speech and Hearing Research, 13, 556-583, 1970.

Keller, E. Parameters for vowel substitutions in Broca's Aphasia. Brain and Language, 5, 265-285, 1978.

Kent, R.D. en Rosenbek, J.C. Prosodic disturbance and neurologic lesion. Brain and Language, 15, 259-291, 1982.

Kent, R.D. en Rosenbek, J.C. Accoustic patterns of apraxia' of speech. Journal of Speech and Hearing Research, 26, 231-249, 1983.

La Pointe, L.L. en Johns, D.F. Some phonemic characteristics in apraxia of speech. Journal of Communication Disorders, 18 259-269, 1975

La Pointe, L.L. Apraxia of speech and its management. Ongepublisecrde referaat voorgedra by die agste jaarlikste kursus in gedragsneurologie en neuropsigologie, Florida, V.S.A., 1982;

Martin, A.D. Some objections to the term apraxia of speech. Journal of Speech and Hearing Disorders, 39, 53-64, 1974 .

Miceli, G., Gainotti, G., Caltagitone, C. en Masullo, C. Some aspects of phonological impairment in aphasia. Brain and Language, 11, 159-169, 1980.

Rosenbek, J.C. Apraxia of speech - relationship to stuttering. Jour nal of Fluency Disorders, 5, 233-254, 1980.

Shankweiler, D.P. en Harris, K.S. An experimental approach to the problem of articulation in aphasia. Cortex, 2, 277-297, 1966.

Trost, J.E. en Canter, G.J. Apraxia of speech in patients with Broca's aphasia: A study of phoneme production accuracy and error patterns. Brain and Language, 1, 63-79, 1974.

Van der Merwe, A. Die motoriese beplanning van spraak, by verbale apraksie. Ongepubliseerde D.Phil-verhandeling. Úniversiteit van Pretoria, 1986.

Van der Merwe, A., Uys, I.C., Loots, J.M. en Grimbeek, R.J. Die invloed van sekere kontckstuele faktore op die ouditief waar. neembare foute by verbale apraksie.' Die Suid-Afrikaanse Tydskrif vir Kommunikasieafwykings, 34, 10-22, 1987

Wertz, R.T., La Pointe, L.L. en Rosenbek, J.C. Apraxia of Speech in Adults: The Disorder and its Management. Orlando: Grune \& Stratton, Inc., 1984. 